\title{
Preverjanje Matematičnega Znanja
}

\section{Potrjeno / \\ Accepted \\ 30.05 .2018 \\ Objavljeno / \\ Published \\ 21.06.2018}

Ključne besede: matematično znanje; nacionalno preverjanje znanja; dosežki;

interno ocenjevanje; zaključne ocene

Keywords: mathematical knowledge; national assessment of knowledge; achievements; internal knowledge assessment; final grades

UDK/UDC 37.091.279.7:51

\section{DARJO FELDA ${ }^{1}$}

${ }^{1}$ Univerza na Primorskem, Pedagoška fakulteta, Koper, Slovenija

\section{CORRESPONDING AUTHOR/KORESPONDENČNI AVTOR darjo.felda@pef.upr.si}

Povzetek/Abstract Matematično znanje se preverja $\mathrm{v}$ šoli, na nacionalnih preverjanjih znanja in v okviru mednarodnih raziskav. Preverjanja znanja imajo različne namene, a vseeno naj bi bila do neke mere uglašena. V zadnjih desetletjih se je $\mathrm{v}$ slovenskih osnovnih šolah močno povečal delež učencev $\mathrm{Z}$ nadpovprečnimi ocenami, primerjava zaključnih ocen v 9. razredu osnovne šole in dosežkov na nacionalnem preverjanju znanja pa nakazuje potencialno neobjektivnost šolskih ocen pri matematiki, kar pod vprašaj postavlja njihov smisel. Prav nacionalno preverjanje znanja, katerega dosežki so usklajeni z dosežki mednarodnih raziskav (TIMSS), bi lahko uporabili za usklajevanje kriterijev vrednotenja znanja in postopoma zagotovili objektivnejše in pravičnejše ocenjevanje.

Assessing Mathematical Knowledge Mathematical knowledge is assessed at school, in national assessments of knowledge and as part of international research studies. Different knowledge assessments have distinct aims, but they should nevertheless be broadly comparable. In recent decades, Slovenian primary schools have seen a major increase in the share of students with aboveaverage achievements. However, a comparison of final grades in Grade 9 of primary school with results from the national assessment of knowledge indicates the potentially subjective nature of school grades in mathematics, which would seem to question their purpose. The national assessment of knowledge, whose results correspond with the results of international studies (TIMSS), could be used to adjust knowledge assessment criteria and gradually ensure that knowledge assessment becomes fairer and more objective. 


\section{Uvod}

$S$ preverjanjem znanja matematike se da najbrž najbolj učinkovito spremljati in posledično izboljševati učenje in poučevanje matematike. $\mathrm{V}$ poročilu EACEA/Eurydice (2009) je bilo ugotovljeno, da so nacionalna preverjanja razširjena praksa $\mathrm{v}$ evropskih izobraževalnih sistemih. Rezultati nacionalnih preizkusov se uporabljajo za spremljanje in vrednotenje šole ali sistema kot celote. Nacionalni preizkusi se manj pogosto uporabljajo za formativne namene, to je za opredeljevanje posebnih učnih potreb učencev. Tudi predmet preverjanja se lahko razlikuje, preverjajo se lahko osnovna znanja matematike, ključne spretnosti računanja ali pa morda raven doseganja matematične kompetence (EACEA/Eurydice, 2011), vendar bo treba še raziskati, kašen je vpliv nacionalnih testov na uspešnost učencev in šol ter na splošno kakovost učenja (EACEA/Eurydice, 2009).

Glavni cilj nacionalnega preverjanja je oceniti kakovost učnih izidov, ki so bili pridobljeni v šolah. Pomembno je omeniti, da se nacionalno preverjanje razlikuje od zunanjega ocenjevanja, pri katerem je glavni poudarek na posameznem učencu in na oceni njegovega znanja (njegovih dosežkov) zaradi izbora za nadaljnje izobraževanje (Postlethwaite in Kellaghan, 2008). Z nacionalnim preverjanjem naj bi ugotovili:

- kako dobro se učenci učijo v izobraževalnem sistemu (glede na splošna pričakovanja, doseganje ciljev iz učnega načrta ter pripravo za nadaljnje učenje in življenje);

- ali obstajajo očitne prednosti in pomanjkljivosti $\mathrm{v}$ znanju in sposobnosti učencev;

- ali določene podskupine v populaciji dosegajo slabše rezultate;

- kateri dejavniki so povezani z dosežki učencev;

- ali se dosežki učencev skozi čas spreminjajo (Greaney in Kellaghan, 2008). Nacionalna preverjanja znanja naj bi vzdrževala dovolj visoko stopnjo odgovornosti posameznih šol, kar pripomore $\mathrm{k}$ razvoju vzgoje in izobraževanja nasploh, h konkurenčnosti znanja $\mathrm{v}$ širšem pomenu besede in tudi k mednarodni primerljivosti znanja (Kim, Lee in Kim, 2016).

Še posebej so ocene oziroma dosežki preverjanj deležni takih in drugačnih presojanj ob zaključku osnovnošolskega izobraževanja, saj je učni uspeh odločilen pri vpisu v srednje šole, postavlja pa se vprašanje, ali je plod pravičnega šolskega (internega) ocenjevanja. Za učence je pravično ocenjevanje tisto, ko za enako izkazano znanje prejmejo enako oceno oziroma ko učitelji uporabijo za učence enake kriterije ocenjevanja (Kodelja, 2006). Vendar pa Semen (2010) izpostavlja, da bi morali vsi učitelji $\mathrm{v}$ državi vrednotiti enako znanje vseh učencev $\mathrm{z}$ enakimi kriteriji, če 
predpostavimo, da je pravičnost ocenjevanja določena z enako oceno za enako znanje. Toda $\mathrm{v}$ praksi se dogaja, da učitelji uporabljajo različne kriterije, saj na ocenjevanje vplivajo različni dejavniki, šolska ocena pa zato poleg izkazanega znanja odraža še mnoge druge prvine, kakor opisujeta Bucik (2001) in Kodelja (2006).

Zaključne ocene učencev niso $\mathrm{v}$ skladu z njihovimi dosežki na nacionalnih preverjanjih znanja (NPZ), saj le za nekatere učence velja, da boljša zaključna ocena v šoli predstavlja višji dosežek na NPZ, slabša zaključna ocena v šoli pa nižji dosežek na NPZ, to pa odpira vprašanje, katero izmed teh dveh merjenj znanja je bolj objektivno (Semen, 2010). Dobre merske karakteristike NPZ, zelo visoki razponi odstotnih točk na NPZ za posamezne zaključne ocene, veliko učencev z visokimi zaključnimi ocenami in nizkimi dosežki na NPZ ter slaba kakovost znanja matematike, ki jo na NPZ pokaže veliko učencev z zaključno oceno odlično, kažejo na objektivnejše merjenje znanja z NPZ (prav tam).

\section{Empirična raziskava}

Namen raziskave

Namen raziskave je preveriti povezanost zaključnih šolskih ocen pri matematiki $\mathrm{v}$ 9. razredu $\mathrm{v}$ šolskem letu 2015/16 z dosežki na nacionalnem preverjanju znanja matematike leta 2016. Zanimalo nas je tudi, kako je $s$ t. i. inflacijo šolskih ocen, to je $z$ višanjem deleža učencev $z$ višjimi ocenami.

\section{Metodologija}

Uporabili smo rezultate nacionalnega preverjanja znanja matematike, ki se vsako leto pripravi $\mathrm{v}$ skladu $\mathrm{z}$ Izhodišči nacionalnega preverjanja znanja $\mathrm{v}$ osnovni šoli (Izhodišča NPZ v osnovni šoli, 2005). Preverjajo se doseganje standardov znanja, ki so zapisani v učnem načrtu, različne vrste in ravni znanja. Leta 2016 je bilo na nacionalnem preverjanju znanja matematike 9 nalog različnih tipov, taksonomskih stopenj in matematičnih vsebin. Indeksi težavnosti posameznih nalog so bili med 0,40 in 0,72 , le ena naloga je imela indeks težavnosti 0,34 . Indeksi diskriminativnosti nalog so bili z izjemo ene naloge (ki je imela indeks 0,28 ) med 0,57 in 0,68 , kar pomeni, da so naloge dobro razločevale med učenci. Indeks zanesljivosti preizkusa je bil 0,94 (RIC, 2016).

Nacionalnega preverjanja znanja matematike se je v maju 2016 udeležilo 16648 učencev 9. razreda osnovne šole, izmed katerih je imelo pri matematiki 21,0\% zaključno oceno odlično, 25,2 \% prav dobro, 24,5\% dobro, 27,5\% zadostno in 1,8 $\%$ nezadostno. Učenci so na nacionalnem preverjanju znanja dosegli v povprečju $51,5 \%$ točk (prav tam).

Zaključne šolske ocene pri matematiki smo primerjali tudi z matematičnimi dosežki v okviru mednarodnih raziskav TIMSS v letih 2011 (Mullis, Martin, Foy in Arora, 2012) in 2015 (Mullis, Martin, Foy in Hooper, 2016). 


\section{Povezanost šolskih ocen z. dosę̌ki na nacionalnem preverjanju znanja matematike}

Oglejmo si, kako so bile zaključne ocene pri matematiki v 9. razredu osnovne šole v šolskem letu 2015/16 povezane z dosežki na nacionalnem preverjanju znanja matematike leta 2016. Prvi vtis da graf 1.

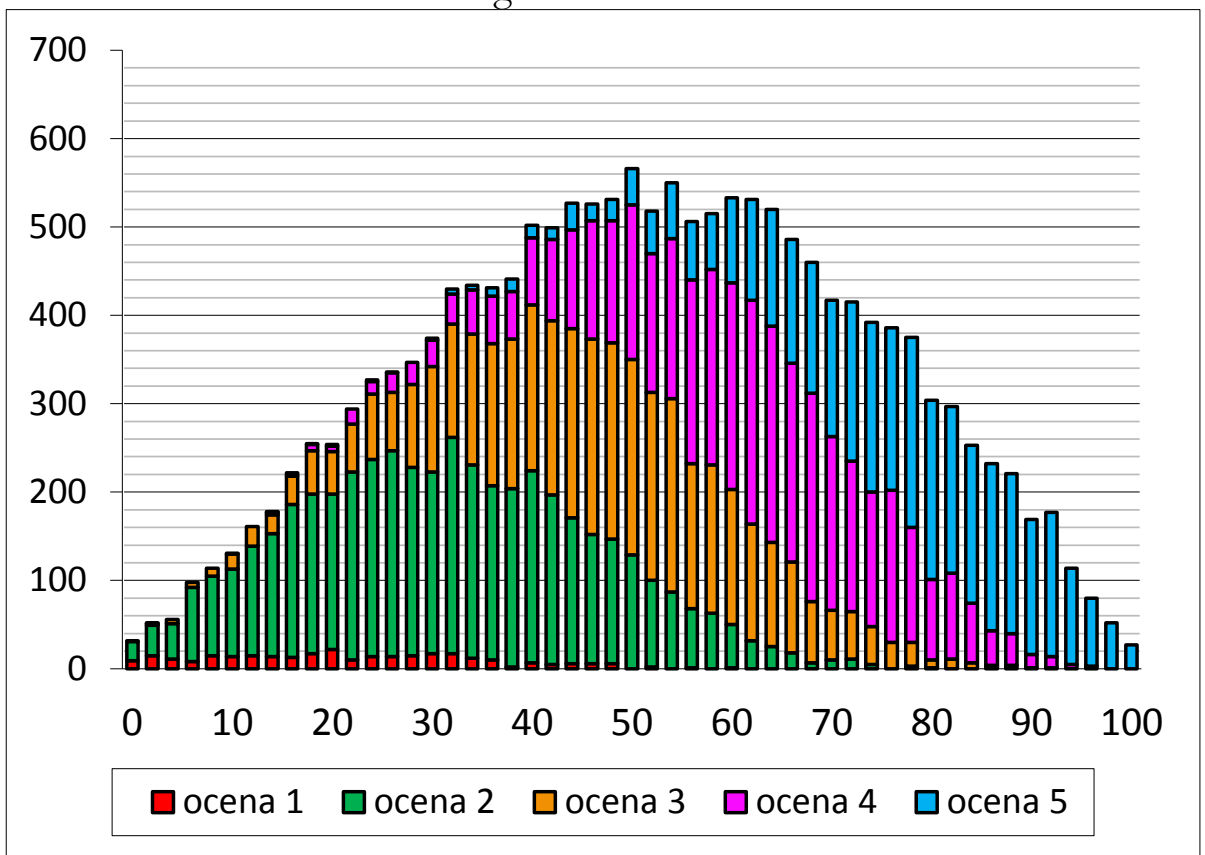

Graf 1: Povezanost šolskih ocen pri matematiki in dosežkov na nacionalnem preverjanju znanja matematike 2016 (vir: Ric)

Povezanost ocen pri matematiki z dosežki na nacionalnem preverjanju znanja matematike lahko natančneje ponazorimo z razpršenostjo dosežkov $v$ posamezni skupini učencev, v kateri so učenci z enako zaključno oceno pri matematiki (graf 2).

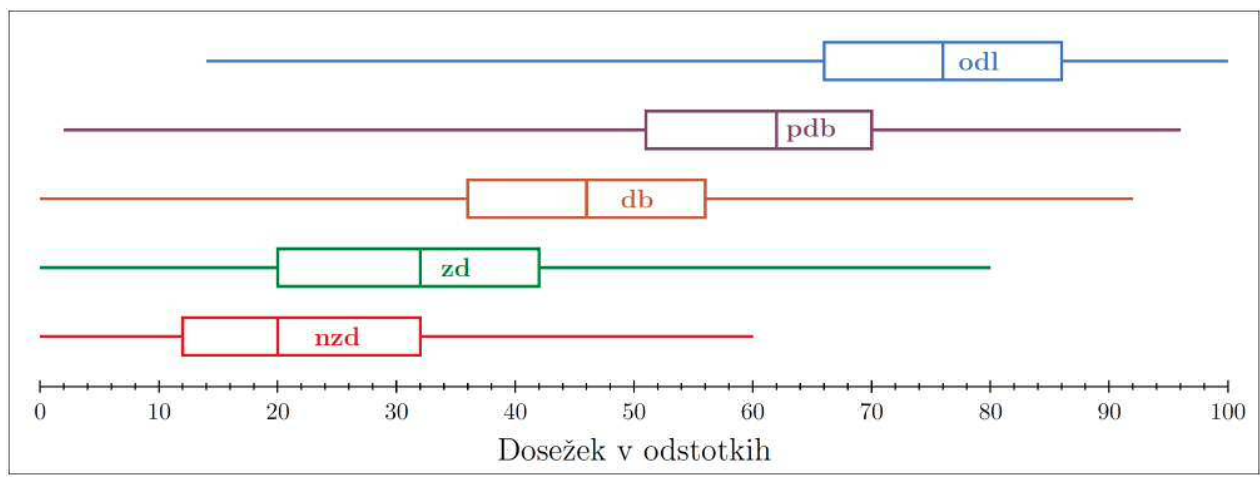

Graf 2: Razpršenost dosežkov na NPZ glede na posamezno zaključno oceno 
Z grafa 2 je razvidno, da se mediane dosežkov posameznih skupin sicer pomikajo v smeri višjega dosežka. Tako je mediana dosežkov učencev, ki so imeli pri matematiki v 9. razredu zaključeno oceno nezadostno, enaka $20 \%$, mediana dosežkov učencev, ki so imeli oceno odlično, pa $76 \%$. Variacijski razmiki dosežkov so relativno veliki; pri učencih, katerih zaključna ocena je bila nezadostno, zadostno ali dobro, je najnižji dosežek $0 \%$, najvišji dosežek pa je $60 \%$ za učence z oceno nezadostno, $80 \%$ za učence z oceno zadostno oziroma $92 \%$ za učence $z$ oceno dobro. Učenci z oceno prav dobro so imeli najnižji dosežek $2 \%$ in najvišji $96 \%$, učenci z oceno odlično pa najnižji dosežek $14 \%$ in najvišji $100 \%$.

\section{Hipoteticne ocene na nacionalnem preverjanju znanja 2016}

Nacionalni preizkusi znanja matematike so v šolskih letih od 2001/02 do 2004/05 prinašali oceno, ki je vplivala na končno zaključno oceno pri matematiki v 9. razredu. Tedanja predmetna komisija za matematiko je poudarila, da se je pri porazdelitvi ocen, ki jih je oblikovala na osnovi dosežkov nacionalnega preizkusa znanja matematike, zgledovala po porazdelitvi ocen, ki so jih učitelji matematike dodelili učencem ob zaključku 9. razreda (RIC, 2005). Nacionalna preverjanja znanja od šolskega leta 2005/06 dalje nimajo več te funkcije. Lahko pa hipotetično pogledamo, kako bi se porazdelile ocene, če bi se v letu 2016 držali enakega pravila. Izmed 16648 učencev 9. razreda osnovne šole je 298 učencev $(1,8 \%)$ imelo zaključno oceno nezadostno, zato bi postavili, da prav toliko učencev z najnižjimi dosežki na NPZ prejme hipotetično oceno nezadostno. Glede na konkretne dosežke so potrebne korekcije, saj je 238 učencev na NPZ doseglo $6 \%$ vseh točk ali manj, 352 učencev pa $8 \%$ vseh točk ali manj. Za število učencev, ki so imeli pri matematiki zaključno oceno nezadostno, to je 298, velja $238<298<352$ in odločimo se za »manj strogo« različico ter hipotetično oceno nezadostno damo učencem, ki so dosegli $6 \%$ vseh točk ali manj. Če na podoben način postavimo meje še za druge hipotetične ocene, bi bila spodnja meja za oceno zadostno $8 \%$ točk, za oceno dobro $38 \%$, za oceno prav dobro $54 \%$, za oceno odlično pa $70 \%$. $\mathrm{V}$ preglednici 1 podrobneje predstavimo, koliko učencev (f) vsake skupine učencev s posamezno zaključno oceno bi prejelo določeno hipotetično oceno in koliko odstotkov (f \%) učencev skupine to predstavlja. 
Preglednica 1: Povezanost zaključnih ocen učencev 9. razreda pri matematiki z dosežki na NPZ oziroma pripadajočimi hipotetičnimi ocenami

Zaključna Hipotetična ocena

\begin{tabular}{ccccccccccc} 
Ocena $v$ \\
\cline { 2 - 11 } 9. razredu & \multicolumn{2}{c}{ Nezadostno } & \multicolumn{2}{c}{ Zadostno } & \multicolumn{2}{c}{ Dobro } & \multicolumn{2}{c}{ Prav dobro } & \multicolumn{2}{c}{ Odlično } \\
\cline { 2 - 11 } & $\mathrm{f}$ & $\mathrm{f} \%$ & $\mathrm{f}$ & $\mathrm{f} \%$ & $\mathrm{f}$ & $\mathrm{f} \%$ & $\mathrm{f}$ & $\mathrm{f} \%$ & $\mathrm{f}$ & $\mathrm{f} \%$ \\
\hline Nezadostn & 43 & 14,43 & 219 & 73,49 & 34 & 11,41 & 2 & 0,67 & 0 & 0,00
\end{tabular}

\begin{tabular}{|c|c|c|c|c|c|c|c|c|c|c|}
\hline Zadostno & 180 & 3,93 & 2731 & 59,64 & 1290 & 28,17 & 348 & 7,60 & 30 & 0,66 \\
\hline Dobro & 14 & 0,34 & 1042 & 25,58 & 1645 & 40,38 & 1126 & 27,64 & 247 & 6,06 \\
\hline $\begin{array}{c}\text { Prav } \\
\text { dobro }\end{array}$ & 1 & 0,02 & 267 & 6,36 & 938 & 22,35 & 1803 & 42,98 & 1187 & 28,29 \\
\hline Odlično & 0 & 0,00 & 29 & 0,83 & 203 & 5,80 & 822 & 23,48 & 2447 & 69,89 \\
\hline Skupaj & 238 & 1,43 & 4288 & 25,76 & 4110 & 24,69 & 4101 & 24,63 & 3911 & 23,49 \\
\hline
\end{tabular}

Iz preglednice 1 je razvidno, da bi učenci, ki so imeli zaključno oceno nezadostno, prejeli hipotetične ocene od nezadostno do prav dobro, učenci, ki so imeli zaključno oceno odlično, pa hipotetične ocene od zadostno do odlično. Učenci, ki so imeli zaključne ocene zadostno, dobro ali prav dobro, bi prejeli hipotetične ocene od nezadostno do odlično. Pokažejo se torej zelo visoki razponi odstotnih točk na NPZ za posamezne zaključne ocene, veliko učencev z visokimi zaključnimi ocenami pa izkazuje nizke dosežke na NPZ. Nekoliko nazorneje lahko to vidimo na grafu 3 .

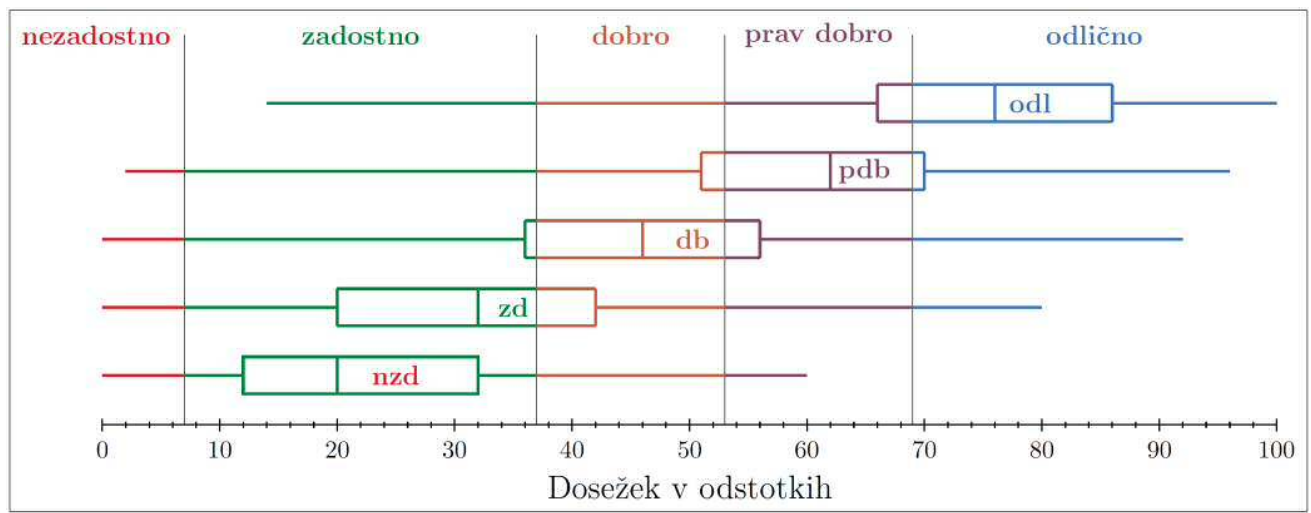

Graf 3: Hipotetične ocene $\mathrm{v}$ povezavi z zaključnimi ocenami

Ti visoki razponi odstotnih točk za posamezne zaključne ocene posledično vplivajo na to, da se hipotetične ocene, ki pripadejo nekaterim učencem, lahko precej razlikujejo od zaključnih, čeprav se hipotetične ocene oblikujejo v smislu zaključnih 
ocen. Lahko bi rekli, da nam vsak učenec preda svojo zaključno oceno in tako zbrane zaključne ocene ponovno razdelimo kot hipotetične, pri čemer veliko učencev ne prejme take ocene, kot jo je predal, nekateri izmed njih pa prejmejo celo bistveno drugačno oceno. S tem se odpirajo vprašanja o (ne)pravičnosti oziroma o (ne)objektivnosti zaključnih ocen. To je le en vidik (ne)pravičnosti oziroma (ne)objektivnosti, saj se delež posameznih zaključnih (internih) ocen zgolj prenese na dosežke NPZ, ne ozira pa se na t. i. inflacijo pri internem ocenjevanju (Zupanc in Bren, 2010). Že Jurman (1989) je opozarjal na inflacijo, ki se je kazala v višanju deleža učencev z višjimi ocenami, upadanju kakovosti znanja in pritiskih na strokovne delavce, da znižajo kriterije pri ocenjevanju znanja.

\section{Inflacija šolskih ocen}

Inflacija ocen se lepo pokaže, če primerjamo zaključne ocene pri matematiki z matematičnimi dosežki v okviru mednarodne raziskave TIMSS v letih 2011 in 2015 oziroma 2016. Dosežki se v okviru TIMSS razdelijo v pet ravni: niti nizka, nizka, srednja, visoka in najvišja raven; primerjali jih bomo $z$ ocenami nezadostno, zadostno, dobro, prav dobro in odlično. Na grafu 4 je primerjava matematičnih dosežkov v okviru mednarodne raziskave TIMSS v letu 2011 (Mullis, Martin, Foy in Arora, 2012), v katero so bili zajeti tedanji učenci 8. razreda, in zaključnih ocen pri matematiki v 9. razredu osnovne šole. Na grafu 5 pa je primerjava matematičnih dosežkov v okviru mednarodne raziskave TIMSS v letu 2015 (Mullis, Martin, Foy in Hooper, 2016), v katero so bili zajeti učenci 8. razreda, in zaključnih ocen, ki so jih leta 2016, torej v 9. razredu osnovne šole, pri matematiki dosegli isti učenci.

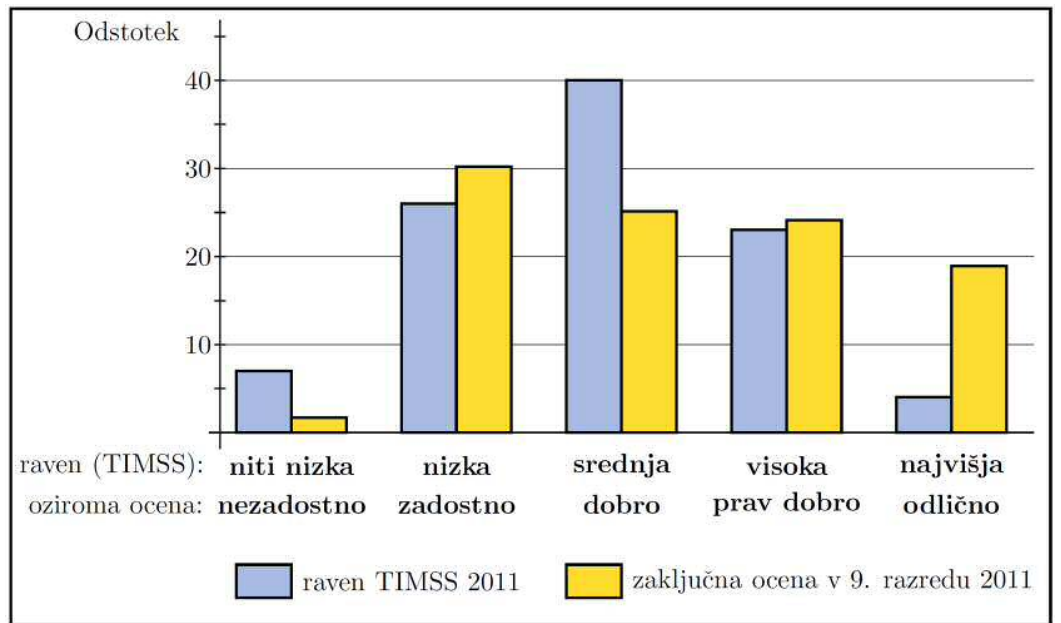

Graf 4: Matematični dosežki učencev leta 2011 na TIMSS in zaključne ocene pri matematiki v 9. razredu osnovne šole 


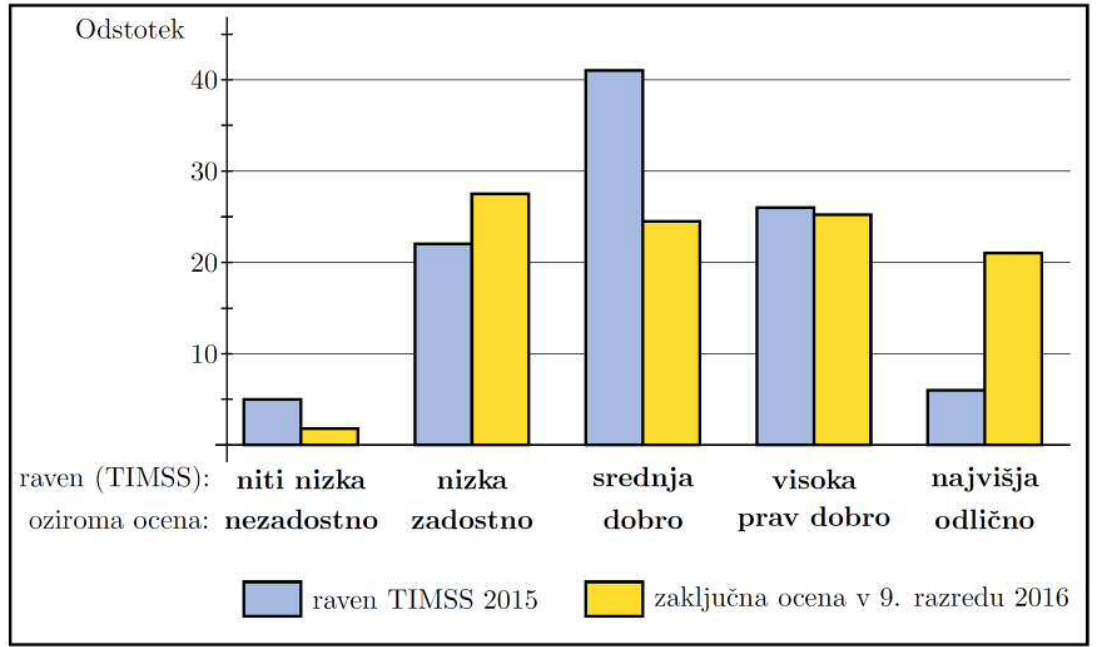

Graf 5: Matematični dosežki učencev leta 2015 na TIMSS ter leta 2016 v 9. razredu

Če se osredotočimo le na zaključne ocene v letih 2011 in 2016, se zdi, da se trend inflacije še ni ustalil. Z grafa 6 razberemo, da je delež učencev z zaključno oceno nezadostno bolj ali manj stalen, medtem ko se delež t. i. nadporprečnih učencev, kakor učence s prav dobrim ali odličnim uspehom opredeljuje Zupanc (2006a), še povečuje.

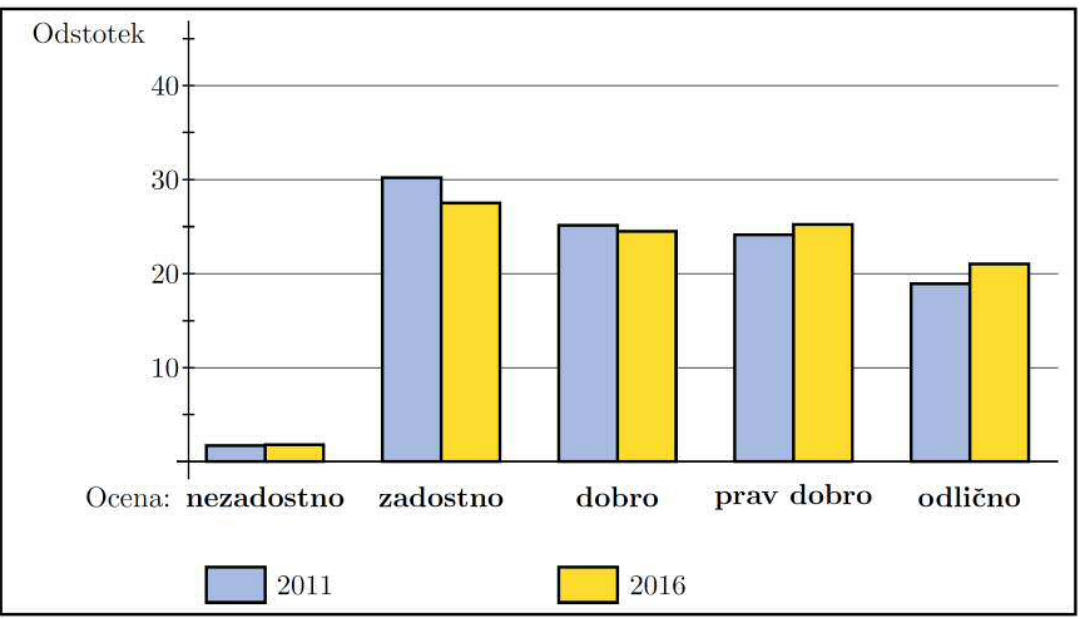

Graf 6: Deleži zaključnih ocen pri matematiki v 9. razredu osnovne šole v letih 2011 in 2016 


\section{Kako do normalne porazdelitve ocen}

Že predmetna komisija za matematiko, ki je v šolskih letih od 2001/02 do 2004/05 pripravljala nacionalne preizkuse znanja matematike, je leta 2002 ob objavi prvih rezultatov izrazila nezadovoljstvo, ker sposobnejši učenci oziroma učenci z visokimi dosežki niso mogli izkazati svojega optimalnega znanja (RIC, 2005). V šolskem letu 2004/05, ko so bile zadnjič podeljene ocene na osnovi dosežkov na NPZ, je namreč $2,29 \%$ učencev prejelo oceno nezadostno, 18,26\% oceno zadostno, 24,72\% dobro, $30,62 \%$ prav dobro in $24,11 \%$ odlično, pri čemer je treba upoštevati, da so odstotki temeljili na porazdelitvi zaključnih ocen pri matematiki $\mathrm{v} 9$. razredu osnovne šole (prav tam).

V nacionalne preizkuse znanja je komisija postopoma vključevala tipe nalog, ki jih v dotedanjih učbeniških gradivih ni bilo in jih učitelji (še) niso vključevali v proces poučevanja, na primer naloge, ki jih rešujemo s kompleksnim in problemskim znanjem, naloge s preveč podatki ipd. Predmetna komisija je na ta način želela $\mathrm{v}$ kulturo preverjanja vnesti širše razumevanje matematičnega znanja - sčasoma naj bi bile v preizkuse vključene naloge, s katerimi bi ugotavljali opravilno znanje (prav tam) ter s tem dali priložnost sposobnejšim učencem, da bi se izkazali znotraj (pre)široke množice prav dobrih in odličnih.

Od šolskega leta 2005/06 je bolj poudarjen formativni namen preverjanja pomembna je informacija, ki jo o pričakovanem znanju in doseganju ciljev daje NPZ vsem udeležencem: učencem, staršem, učiteljem, šolam in drugim ustanovam, ki skrbijo za izobraževanje (Magajna in Žakelj, 2011). Z dosežki učencev na NPZ naj bi učitelji pridobili dodatne informacije o znanju svojih učencev in o njihovem doseganju standardov iz učnih načrtov, ob strokovni analizi nalog in dosežkov pa naj bi učitelji kritično ovrednotili svoje poučevanje in usklajevali svoje kriterije vrednotenja znanja s kriteriji drugih učiteljev (Izhodišča NPZ, 2005). Medtem ko so bili preizkusi znanj do leta 2005 bistveno občutljivejši na spodnjem delu ocenjevalne lestvice, je od leta 2006 občutljivost enakomernejša (Magajna in Žakelj, 2011).

Čeprav je torej med posrednimi cilji NPZ zagotavljanje bolj enotnih kriterijev učiteljevega ocenjevanja (Izhodišča NPZ, 2005), ta cilj še zmeraj ni dosežen. Dosežki nacionalnih preverjanj znanja matematike so vsako leto dokaj normalno porazdeljeni in kot taki nakazujejo, da bi se morale tudi ocene temu prilagoditi. Trenutno še ni znano, ali bo prišlo do sprememb pri NPZ, se pa kot ena izmed možnosti nakazuje, da bi bil dosežek nacionalnega preverjanja znanja matematike le ena izmed ocen, ki naj bi poleg učiteljevih ocen vplivala na zaključno oceno pri matematiki. Če bo obveljala ta možnost, bo vpliv dosežka nacionalnega preverjanja na zaključno oceno relativno omejen, a bo vendarle nakazoval trend k normalnejši 
porazdelitvi. Seveda je jasno, da omenjenega cilja ne bomo dosegli, če bomo dosežke prelevili $\mathrm{v}$ ocene $\mathrm{v}$ smislu (pričakovanih inflatornih) zaključnih ocen, pač pa bi bilo treba dosežke na NPZ bolj »normalno« preoblikovati v ocene. Tedaj bi lahko dosežke naših učencev oziroma ustrezno (normalno) oblikovane ocene z NPZ primerjali z dosežki učencev iz drugih držav. Če pogledamo, koliko odstotkov učencev se uvrsti na posamezno mesto $\mathrm{v}$ petstopenjski lestvici (kar bi lahko ustrezalo ocenam od nezadostno do odlično ali ravnem znanja od niti nižka do najuišja) v nekaterih državah (preglednica 2), ugotovimo, da se z odstotki »inflatornih« ocen seveda ne moremo primerjati.

Preglednica 2: Odstotki učencev po posameznih mestih v petstopenjski lestvici v nekaterih državah (vir: Zupanc, 2006b)

Država

Raven znanja

\begin{tabular}{cccccc} 
& Niti nizka & Nizka & Srednja & Visoka & Najvišja \\
\hline Švedska & 13 & 22 & 29 & 27 & 9 \\
\hline Anglija & 8 & 17 & 48 & 21 & 6 \\
\hline ZDA & 9 & 23 & 39 & 23 & 6 \\
\hline Kanada - Ontario & 12 & 28 & 35 & 24 & 1 \\
\hline Kanada - Quebec & 11 & 18 & 34 & 36 & 1 \\
\hline Avstralija - ACT & 11 & 24 & 36 & 21 & 8
\end{tabular}

\section{Zaključek}

Dosežki učencev na NPZ dajejo pomembne informacije učencem, staršem, učiteljem, šolam in strokovnim institucijam (Izhodišča NPZ, 2005), sami po sebi pa seveda ne odpravljajo zagat (ne)objektivnosti in (ne)pravičnosti. Vsak, ki so mu informacije namenjene, bi moral imeti svoj del odgovornosti in dolžnosti, da poseže $\mathrm{v}$ postopno razreševanje problemske situacije, $\mathrm{v}$ kateri smo se kot družba znašli. Že desetletja prihajajo opozorila o naraščanju števila »nadpovprečnih učencev«, ki zaključujejo osnovnošolsko izobraževanje, in vrstijo se vprašanja, ali niso morda vzgojno-izobraževalni cilji postavljeni prenizko (Zupanc, 2006b). Na vprašanje, ali smo se v Sloveniji držali usmeritve o spodbujanju vključevanja čim širšega dela populacije mladih v splošno ali strokovno srednje izobraževanje in o povečanju prehodnosti med raznimi segmenti izobraževalnega sistema ob obranjanju ravni zabtevnosti, kakor je zapisano v Beli knjigi (1995), posredno odgovarja kar (nova) Bela knjiga (2011), v kateri najdemo podatke, ki so zgovorni sami po sebi:

- 54,9 \% anketiranih učiteljev na gimnazijah ocenjuje, da so učitelji, ki poučujejo na njihovi šoli, $v$ zadnjih desetih letih pri ocenjevanju zelo znižali ali znižali kriterije zahtevnosti;

- 30,6 \% učiteljev meni, da so učitelji le nekoliko znižali kriterije; 
- $\quad$ 11,1 \% učiteljev meni, da učitelji v zadnjih desetih letih pri ocenjevanju niso znižali kriterijev;

- 48,6 \% ravnateljev ocenjuje, da so učitelji pri ocenjevanju nekoliko znižali kriterije ocenjevanja;

- $\quad 24,3 \%$ ravnateljev meni, da so jih zelo znižali ali znižali;

- $27,0 \%$ ravnateljev pa meni, da jih niso znižali.

Tudi v drugih državah se izkazuje, da so učitelji na splošno bolj »radodarni« in da imajo učenci nekoliko višje šolske (interne) ocene od ocen ali dosežkov, ki jih pridobijo na nacionalnih preverjanjih, kar je še posebej značilno za ocene pri matematiki (Lindahl, 2007), a razlike še zdaleč niso tako izrazite kot v Sloveniji. Z »radodarnostjo lahko prestopimo prag objektivnosti in pravičnosti - če že ne znotraj posamezne šole, pa skoraj zagotovo med šolami. Zato je treba upoštevati nacionalno preverjanje znanja kot pomemben element ugotavljanja in zagotavljanja kakovosti šolskega dela (Gosak, Ivanuš Grmek in Čagran, 2016). Prav zaradi tega, ker je nacionalno preverjanje znanja eden izmed pomembnih pokazateljev znanja učencev in ker poleg znanja učencev pri predmetih, ki se preverjajo, pokaže tudi kakovost celotnega vzgojno-izobraževalnega sistema (Škalič in Ivanuš Grmek, 2017), bi bili lahko dosežki nacionalnega preverjanja znanja dobra osnova za postopno deflacijo pretiranega deleža nadpovprečnih učencev, hkrati pa bi lahko zagotavljali objektivnejše in pravičnejše ocenjevanje.

\section{Summary}

Assessing mathematical knowledge enables us to monitor and thus improve the learning and teaching of mathematics. A special role is played by national assessments of knowledge, a widespread practice in European education systems. The main goal of a national assessment of knowledge is to evaluate the quality of the learning outcomes achieved in schools. School grades and assessment results are scrutinized particularly at the end of primary-school education in Slovenia, since children's final grades can be decisive in their enrolment in secondary school. Thus, the question arises whether the grades are the product of a fair process of (internal) school assessment. Students' final grades in mathematics do not accord with their achievements in the national assessment of knowledge, which measures knowledge more objectively than school grades. In 2016, 16,648 Year 9 students participated in the national assessment of mathematical knowledge. Their final grades in mathematics were as follows: excellent (21.0\% of the students); very good $(25.2 \%)$; good $(24.5 \%)$; satisfactory $(27.5 \%)$ and failing $(1.8 \%)$. In the national assessment of knowledge, they earned an average mark of $51.5 \%$. The range of the achievements was relatively wide: the students whose final grades were failing, satisfactory or good 
scored between $0 \%$ and $60 \%$ (those with a failing grade), between $0 \%$ and $80 \%$ (those with a satisfactory grade) and between $0 \%$ and $92 \%$ (those with a good grade). Students with a very good final grade scored between $2 \%$ and $96 \%$, and students with a grade of excellent, between $14 \%$ and $100 \%$. Clearly, this raises the question of the (un)fairness and (non-)objectivity of the final grades.

Moreover, a comparison of final mathematics grades and the TIMSS 2011 and 2015 international results reveals the problem of grade inflation: based on the final grades, the share of above-average students (i.e. students with grades of very good or excellent) is disproportionately high. Although the indirect objectives of the national assessment of knowledge include ensuring more unified criteria for teachers' assessment of students' knowledge, this has still not been achieved despite decades of warnings regarding the increasing number of above-average students completing primary-school education, and despite continuous questions about the likelihood of educational goals being set too low. We have evidently not followed the course of encouraging participation by as many students as possible in general and technical or vocational education and of enhancing the transition among various segments of the education system, while also retaining the level of difficulty, as stated by the White Paper on Education in the Republic of Slovenia. In other countries, too, teachers seem to be generally more "generous", and students achieve somewhat higher school (internal) grades compared to external assessment results, which is especially true of grades in mathematics. Nevertheless, the differences are far less significant than in Slovenia. Such "generosity" may take us beyond the bounds of objectivity and fairness - if not within individual schools, then almost certainly among schools in general. This makes it crucial to take account of the national assessment of knowledge as an important element in the assessment and assurance of school work quality. Because the national assessment of knowledge is an important indicator of students' knowledge and because, in addition to students' knowledge of tested subjects, it also indicates the quality of the entire education system, the results of the national assessment of knowledge could provide a sound basis for a gradual deflation of the excessive share of aboveaverage students, while also ensuring a form of knowledge assessment that is fairer and more objective.

\section{Literatura}

Bela knjiga o vzgoji in izobraževanju v Republiki Sloveniji (1995). Ljubljana: Ministrstvo za šolstvo in šport.

Bela knjiga o vzgoji in izobraževanju v Republiki Sloveniji (2011). Ljubljana: Zavod RS za šolstvo. Pridobljeno s http://pefprints.pef.uni-lj.si/1195/1/bela_knjiga_2011.pdf (16. 01. 2018)

Bucik, V. (2001). Zakaj potrebujemo kakovostno zunanje preverjanje in ocenjevanje znanja. Sodobna pedagogika, 52 (3), 40-52. 
EACEA/Eurydice (2009). National Testing of Pupils in Europe: Objectives, Organisation and Use of Results. Brussels: Eurydice.

EACEA/Eurydice (2011). Mathematics Education in Europe: Common Challenges and National Policies. Brussels: Eurydice.

Gosak, F., Ivanuš Grmek, M. in Čagran, B. (2016). Evalvacija in samoevalvacija v osnovni šoli = Evaluation and self-evaluation in basic school. Revija za elementarno izobraževanje, 9 (3), 89-102.

Greaney, V. in Kellaghan, T. (2008). Assessing National Achievement Levels in Education. Washington: World Bank.

Izhodišča NPZ v osnovni šoli (2005). https://www.ric.si/preverjanje_znanja/splosne_informacije/ Jurman, B. (1989). Ocenjevanje znanja: selekcija ali orientacija učencev. Ljubljana: DZS.

Kim, H.-K., Lee, D.-H. in Kim, S. (2016). Trends of Science Ability in the National Assessment of Educational Achievement (NAEA) of Korean Ninth Graders. Eurasia Journal of Mathematics, Science \& Technology Education, 12 (7), 1781-1798.

Kodelja, Z. (2006). O pravičnosti v izobraževanju. Ljubljana: Krtina.

Lindahl, E. (2007). Comparing teachers' assessment and national test results - evidence from Sweden. Uppsala: Institute for Labour Market Policy Evaluation.

Magajna, Z. in Žakelj, A. (2011): Primerjalna analiza zunanjega preverjanja znanja iz matematike ob koncu devetletke v Sloveniji med obdobjema 2002-2005 in 2006-2010. Sodobna pedagogika, 62 (2), 134-156.

Mullis, I. V. S., Martin, M. O., Foy, P. in Arora, A. (2012). TIMSS 2011 International Results in Mathematics. Chestnut Hill: TIMSS \& PIRLS International Study Center, Lynch School of Education, Boston College; Amsterdam: International Association for the Evaluation of Educational Achievement, IEA Secretariat.

Mullis, I. V. S., Martin, M. O., Foy, P. in Hooper, M. (2016). TIMSS 2015 International Results in Mathematics. Chestnut Hill: TIMSS \& PIRLS International Study Center, Lynch School of Education, Boston College. Pridobljeno s http://timssandpirls.bc.edu/timss2015/international-results/ (01. 02. 2018)

Postlethwaite, T. in Kellaghan, T. (2008). National assessments of educational achievement. Paris, Brussels: IIEP, IAE.

RIC (2005). Nacionalni preizkusi znanja. Letno poročilo o izvedbi v šolskem letu 2004/2005. Ljubljana: Državni izpitni center. Pridobljeno s http://www.ric.si/mma/letno\%20poročilo\%20npz\%202005/2006070311492832/ (01. 02. 2018)

RIC (2016). Nacionalno preverjanje znanja. Letno poročilo o izvedbi v šolskem letu 2015/2016. Ljubljana: Državni izpitni center. Pridobljeno s

https://www.ric.si/mma/Letno\%20poro\%20\%20ilo\%20NPZ\%202016/2016122114351304/ (01. 02. 2018)

Semen, E. (2010). Objektivnost meril za izbiro kandidatov pri omejitvi vpisa v programe srednješolskega izobraževanja. Sodobna pedagogika, 61 (2), 164-179.

Škalič, M. in Ivanuš Grmek, M. (2017). Stališča staršev do nacionalnega preverjanja znanja ob koncu drugega vzgojno-izobraževalnega obdobja = Parents' views on the national assessment of knowledge at the end of the second cycle of basic school. Revija za elementarno izobraževanje, 10 (1), $57-71$.

Zupanc, D. (2006a). Inflacija. Šlski razgledi, 62 (9), 1.

Zupanc, D. (2006b). (Mis)use of National Assessment Results in Slovenia. 32nd annual conference: Assessment in an Era of Rapid Change: Innovations and Best Practices. International Association 
for Educational Assessment, Singapore, May $21-26$, 2006. Pridobljeno s http://www.iaea.info/documents/paper_1162a16407.pdf (01. 02. 2018)

Zupanc, D. in Bren, M. (2010). Inflacija pri internem ocenjevanju v Sloveniji. Sodobna pedagogika, 61 (3), 208-228.

\section{Author}

\section{Darjo Felda, Ph.D.}

Associate Professor, University of Primorska, Faculty of Education, Cankarjeva 5, 6000 Koper, Slovenia, e-mail: darjo.felda@pef.upr.si

Izredni profesor, Univerza na Primorskem, Pedagoška fakulteta, Cankarjeva 5, 6000 Koper, Slovenija, e-mail: darjo.felda@pef.upr.si 